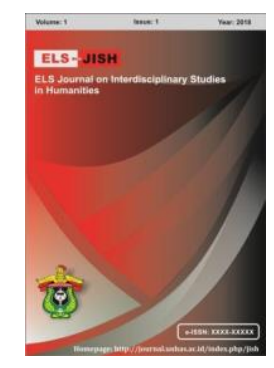

ELS-JISH

ELS Journal on Interdisciplinary Studies on Humanities

Volume 3 Issue 2, 2020

ISSN (print) : 2621-0843

ISSN (online) : 2621-0835

Homepage : http://journal.unhas.ac.id/index.php/jish

\title{
Impact of the Process Genre Approach on the Management Students' Business Writing Skills
}

\section{Bonala Kondal ${ }^{1}$}

\author{
Boko0891@gmail.com
}

\begin{abstract}
In the present corporate world, it is prominent to hone business writing skills among students for becoming good management professionals. Writing is foremost and significant skill in the business world, but most of the students lack proficiency in their writing. The present paper attempts to explore the impact of the process genre approach in teaching business writing skills to the management professionals. The sample of the study consists of 40 management students from a professional college and 32 teachers of English who were working in sixteen different professional colleges. In order to collect the data, the questionnaires were administered to the students as well as to the teachers. Post analysis of the data, it was found that management students' business writing skills had a positive impact when the processgenre approach incorporated in teaching and learning processes. Hence, it is concluded that the use of the process genre approach for teaching business writing to the management students during the intervention had become successful in achieving the desired goal. It also aided the students in developing better writing proficiency and enhancing their business writing skill.
\end{abstract}

Keywords: Business Writing Skills, Business Writing, Process-Genre Approach, Management Students

How to cite: Kondal, B. (2020). Impact of the Process Genre Approach on the Management Students' Business Writing Skills. ELS Journal on Interdisciplinary Studies in Humanities, 3(2), 297-307. DOI: 10.34050/els-jish.v3i2.9721

\section{Introduction}

In the present business world, it is foremost and significant to master business writing skills among the students to become good management professionals. It is a way of communicating information clearly and precisely in a professional context. All the business professionals require good writing skills in order to convey ideas and concepts appropriately to transact business communication effectively. It is absolutely indispensable for business people to provide various instructions and orders clearly in well-written communication for better comprehension and compliance. Business writing is playing a remarkable role in the business world and in the field of international trade and commerce. According to Nordquist (2018, June 17) business writing consists of a variety of writing such as 'reports, proposals, memorandums, e-mails and

${ }^{1}$ Malla Reddy Engineering College, India 
other forms of communication which are used in various organizations for communicating with both internal and external audiences (Para. 1).

Business writing requires more formal language and professional style than other kinds of writing. It is precise, legible, logical and easy to understand in professional context/setting. Business writing as a skill is usually neglected in professional colleges because the focus of the students is mainly on professional subjects rather than on English language or the four language skills. Management students experience difficulties in producing various types of written communication especially writing business reports and proposals as part of their curriculum. Learners in management colleges are unaware of different elements of business writing such as format, structure and organization due to lack of proper exposure and inadequate knowledge of business writing.

The present research problem emerged out of a keen examination of the business management students' written scripts and writing skills in business management colleges located in and around Hyderabad, on the basis of the findings of a pilot study.

The present study is significant because developing business writing skills among management students at the tertiary level is a noteworthy effort. Moreover, the study endeavors to present some remedies for students' writing difficulties, paving the way for the students to overcome different challenges.

The study attempts to find out the answers to the following research questions

- What are the difficulties that management students faced in business writing?

- How would the use of process genre approach in teaching business writing impact management students' business writing skills?

\section{Literature Review}

This section presents the past studies used previously and also provides related theoretical framework. On the other hand, it the researchers argue that learners acquiring language go through various developmental stages. With the help of these stages learners enhance their language performance through lexical density and lexical variety. These stages are similar across the languages. Mohamed Kassem (2017) investigated that use of wikis had a positive effect on management students' business writing as well as it reduced their writing anxiety. In Azhar, Kiran and Khan (2016) study proved that the process genre approach provided practice for the subjects through the process of writing multiple drafts, editing, revising and rewriting thereby improved their writing skills in an academic context. Reonal (2015) study revealed that the process genre approach based lessons provided many chances to the learners to learn the purpose and structure of the expository writing and these lessons improved the students' writing performance in the aspects of the organization, sentence structure and voice.

The study of Pujianto, Emilia \& Sudarsono (2014) focused on the implementation of process genre approach in teaching report writing in a senior 
high school. The findings of the study proved that the students' writing ability improved significantly after the intervention and the students' other language skills were also facilitated (Emilia, 2012). However, it was also found that the teachers' comprehensive knowledge of the concept of process-genre approach as well as the topics and materials used in the intervention also substantially contributed to successful learning in the classroom. The researchers have pointed out that not only the students developed good writing skills in report writing and text knowledge, they also developed genre knowledge and learnt how to gather feedback from peers and teachers. The change was effected through the teaching process, schematic structures and linguistic features analysis. It was also found that the low-achieving students needed longer modeling at teacher-student interaction stages.

For the present study, the following theoretical framework used in order to understand the concepts clearly that help in teaching/learning writing skills. Bandura's Social cognitive Theory (Bandura, 1982, 1986), Vigotsky's Zone of Proximal Development (Vigotsky, 1978), Bruner's Scaffolding and Swain's Collaborative Learning (Swain, 1997, 2000). All these theories conceptualize language learning and development as well as the characteristics of the language learners who involve actively in the writing process.

According to Flower and Hayes (1981), writing is defined as a recursive and complex activity that involves various aspects such as task environment, writer's memory and composing processes. Hence, cognitive approach precisely influenced writing instruction through a process of writing that includes the stages of planning, drafting, revising and editing.

\subsection{Approaches to the Teaching of Writing}

According to Nunan (1999), writing is indeed 'a complex cognitive process that requires sustained intellectual effort over a period of time' (p. 73). Teaching of writing has been transformed over the past four decades characterized by the use of different approaches.

\section{a. The Product Approach to Writing}

Product-oriented approach is a traditional approach to teaching writing which emerged in the 1960s. In this approach, the teachers give importance to a final piece of writing or the end product. The final product is measured by the various factors such as use of vocabulary, correct grammatical use and mechanics of writing - spelling and punctuation as well as content and organization (Brown, 1994, p.320). It focuses on the written products that students compose. The writing exercises involved in this approach deal with sentence-level writing to paragraph-level organization. In addition, students are required to follow a meticulous arrangement, the use of guidelines and key vocabulary provided by the teacher. They rearrange the text according to what is required; that means the knowledge and skills students bring to the classroom are undervalued (Badger \& White, 2000, p. 157). This approach was widely adopted and used in the 1980s by course book writers and teachers. 


\section{b. The Process Approach to Writing}

According to Kroll (1990), the introduction of the process approach to writing was motivated by dissatisfaction with the product approach (p.14). The Process approach focuses more on the stages of writing process than on the final product. This approach consists of six stages such as planning, gathering ideas, drafting, editing, revising and rewriting. Every stage of the writing process assists the students to write freely and arrive at an end product of better quality. Badger \& White (2000) state that the steps/stages in the process approach involve a sequence of actions like choosing a topic, gathering ideas, organizing ideas, drafting, reviewing and revising, and rewriting the final version (p.154).

\section{c. The Genre-based Approach}

The genre approach is defined as a framework for language instruction. The term of each subclass share some communicative functions (Swales, 1990) such as film reviews analyze movies; editorials give ideas about the content of a book, a journal or magazine, and product manuals describe the mode of operation and a set of troubleshooting strategies for a specific gadget. The genre-based approach to writing is regarded as a social and cultural practice. It depends on the type of texts that learners write and also provides students with explicit knowledge about the language. Its focus is on, as the term suggests, particular genres that students are required to learn in order to succeed in particular settings. This approach concentrates on language and discourse features of the texts, as well as the context where the text is produced. When the readers identify the purpose of the text, communication is successful. The teaching instruction based on this view consists of genre approaches to writing (Tribble, 1996). Genre-based teaching helps to develop learners' awareness and comprehension of the conventions of writing so that they can craft wellformed texts. (Tangekiengsirisin, 2006). Genre approach to writing is viewed as writing from the social context perspective. According to Hyland (2003), genres refer to abstract, socially identified ways of using language (p.21). According to Richards et al. (2002), the popularly known genres include business reports, news broadcasts, speeches, letters, advertisements, and so on (p.224). For instance, in a business communication, writing reports and proposals are examples of the genre (Bhatia, 1993).

Therefore, each genre consists of communicative features, organizational structure and linguistic features. Based on the writers' purpose the genre determines the rules and conventions of writing. While using genres in writing classes, the communicative purposes and the structural features are identified. According to Freez and Joyce (1998), the genre-based approach is devised based on the following three assumptions on language learning. 1. Learning language is a social activity that is the result of collaboration between teacher and students and between students and other students in a group (Feez \& Joyce, 1998; Halliday, 1992). 2. Learning occurs more effectively if teachers are clear about what is conventional of students (Feez \& Joyce, 1998). 3. The process of language learning is serious of scaffold steps that address different elements of language (Feez \& Joyce, 1998; Bruner, 1986). According to 
Badger and White (2000), the genre approach is a synthesis of the product and process approaches and the combination of different approaches.

\section{c. The Process Genre Approach to Writing}

Recently many writing instructors have identified the need of adopting one approach in ESL writing classroom by blending different approaches. Based on different perspectives and the nature of writing as well as teaching and learning practices, the process and genre approach to teaching writing has been developed. The process approach emphasizes on individual writers and their cognitive processes in composing a text (Flower \& Hayes, 1981), whereas genre theory gives much attention to social factors which are important for the construction of language and text. Badger and White (2000) proposed the process-genre approach. This approach is generally a blend of process models and genre theories. This came out with realizations of the limitations of both the process and genre approaches in enhancing learners' writing skill (p. 158).

\section{Application of the Process-Genre Approach}

The process-genre approach is used for encouraging students in identifying writing as a cognitive and social activity. For the production of good texts, learners must have awareness of cognitive processes and genre types in a social setting. The role of the teacher is to assist, guide and work closely with students by encouraging and providing the necessary feedback and suggestions. Teaching instruction must provide students the explicit knowledge of genre and process of writing in L2. To put the theory into classroom practice, the present approach was mainly influenced by Feez and Joyce's (1998) model given in the Figure 2.6. The cycle comprised five stages - i) Building the context, ii) Modeling and deconstructing the text, iii) Joint construction of the text, iv) Independent construction of the text and v) Linking related texts.

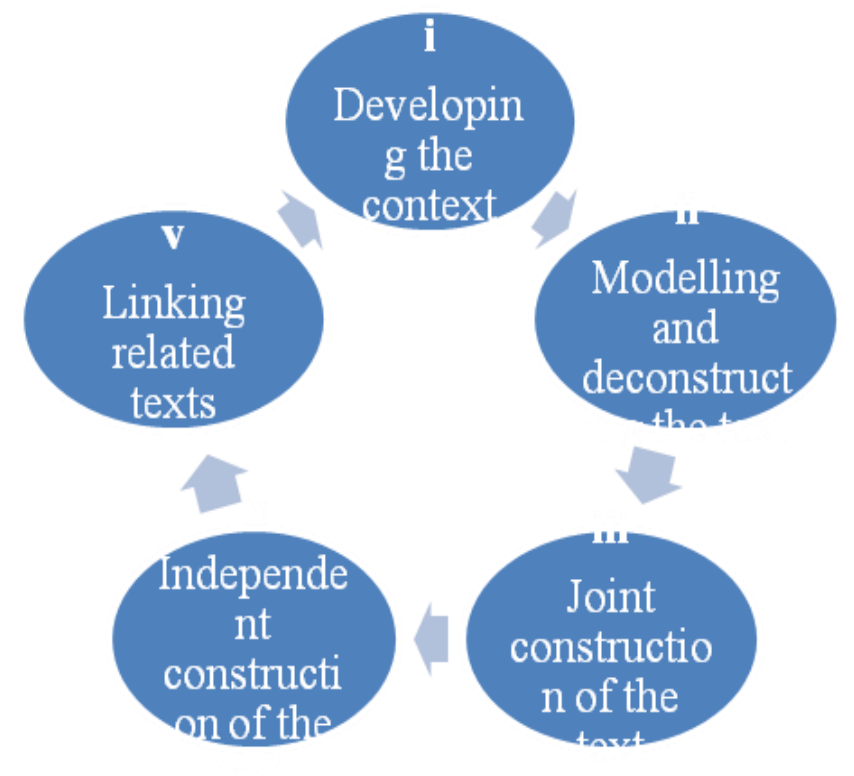

Figure 1. The teaching-learning model (adopted from Feez \& Joyce 1998, p.28.) 


\section{Method}

\subsection{Sample}

The sample for the present study was a group of $401^{\text {st }}$ year management students (MBA students) chosen from one of the professional colleges in Hyderabad. The age group of the sample was between 21-24 years. Though the students were from different language background, their medium of instruction was English in the MBA programme. Some of them had over 15 years of exposure to English and had completed their education through English medium. A few had a maximum of six years exposure to English. The students were from diverse back grounds, urban as well as the rural setting. They had completed graduation with BA/BSc/BCom/BBA and chosen MBA at the post graduation level. In addition, the researcher also selected 32 teachers of English from the sixteen different professional management colleges in the suburban areas of Hyderabad. Among the teachers, eight were female and twenty-four were male teachers. All the selected teachers had MA English as the minimum qualification.

\subsection{Procedure}

The research procedure of the present study had three phases. In the first phase, the questionnaires were administered among the students and teachers. Intervention program was conducted in the second phase. At the end, post intervention questionnaires were administered among students about the intervention program.

\section{Findings}

The data was collected through various research tools such as students' questionnaires and teachers' questionnaires. The obtained data was analyzed and interpreted systematically to address the research questions of the study to know whether anticipated assumptions are proved to be positive. The data analysis helped to know about the students' written performance and to understand their knowledge of text types and their problems in business writing.

The analysis of the questionnaires was presented. The data in the figure 2 shows that $60 \%$ of the students ignore their mistakes after finding them whereas $52 \%$ of them never check their mistakes in their write-ups. $19 \%$ of them rectify their mistakes after finding them, whereas $16 \%$ of them approach the teacher for rectification. $11 \%$ of the students take help from their peer group. On the basis of the above analysis, it is understood that majority of the students ignore their mistakes and do not try to correct them or know the correct form whereas $52 \%$ never check their mistakes in their write ups.

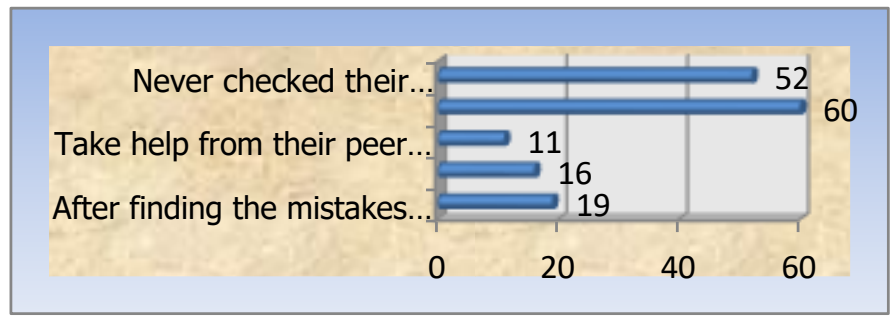

Figure 2. Students' reaction after finding the mistakes 
Table 1. Learning strategies

\begin{tabular}{|c|c|c|c|c|c|c|c|c|c|c|c|}
\hline \multirow[t]{3}{*}{ Item } & \multicolumn{11}{|c|}{ General Writing Strategies } \\
\hline & & \multicolumn{2}{|l|}{5} & \multicolumn{2}{|c|}{4} & \multicolumn{2}{|l|}{3} & \multicolumn{2}{|c|}{2} & \multicolumn{2}{|l|}{1} \\
\hline & Writing Strategies & $\begin{array}{l}\text { Respon } \\
\text { dents }\end{array}$ & $\%$ & $\begin{array}{l}\text { Respon } \\
\text { dents }\end{array}$ & $\%$ & $\begin{array}{l}\text { Respon } \\
\text { dents }\end{array}$ & $\%$ & $\begin{array}{l}\text { Respon } \\
\text { dents }\end{array}$ & $\%$ & $\begin{array}{l}\text { Respo } \\
\text { ndent } \\
\mathrm{s}\end{array}$ & $\%$ \\
\hline 1. & $\begin{array}{l}\text { Write notes, messages, letters, reports and } \\
\text { proposals. }\end{array}$ & 107 & 49 & 64 & 29 & 37 & 37 & 7 & 3 & 2 & .9 \\
\hline 2. & Refer dictionary to produce write ups. & 10 & 04 & 25 & 10 & 48 & 22 & 106 & 49 & 64 & 30 \\
\hline 3. & Use known words in different ways. & 20 & 8 & 68 & 33 & 49 & 23 & 10 & 5 & 82 & 39 \\
\hline \multicolumn{12}{|c|}{ Before Writing } \\
\hline 4. & $\begin{array}{l}\text { Review class notes, handouts and textbook } \\
\text { before beginning to write. }\end{array}$ & 20 & 10 & 72 & 32 & 75 & 35 & 17 & 8 & 10 & 5 \\
\hline 5. & $\begin{array}{l}\text { Consider tasks and instructions carefully before } \\
\text { writing }\end{array}$ & 10 & 5 & 84 & 38 & 36 & 16 & 87 & 39 & 5 & 3 \\
\hline 6. & $\begin{array}{l}\text { Discuss with other students and your teacher } \\
\text { before starting to write. }\end{array}$ & 52 & 23 & 71 & 32 & 55 & 25 & 28 & 13 & 16 & 7 \\
\hline 7. & Brainstorm and write down ideas. & 12 & 5 & 68 & 31 & 52 & 24 & 17 & 8 & 70 & 32 \\
\hline 8. & Initially, outline what you are going to vrite. & 6 & 3 & 68 & 34 & 44 & 22 & 19 & 10 & 62 & 31 \\
\hline 9. & $\begin{array}{l}\text { Before writing the first draft, you do extra } \\
\text { exercises outside the classroom to improve } \\
\text { writing. }\end{array}$ & 20 & 9 & 57 & 26 & 52 & 24 & 41 & 19 & 48 & 22 \\
\hline 10. & $\begin{array}{l}\text { Notice the vocabulary related to a topic and try } \\
\text { to remember the words. }\end{array}$ & 72 & 31 & 16 & 7 & 48 & 21 & 14 & 6 & 84 & 36 \\
\hline \multicolumn{12}{|c|}{ During Writing } \\
\hline 11. & $\begin{array}{l}\text { Use background knowledge to help developing } \\
\text { your ideas. }\end{array}$ & 31 & 14 & 78 & 35 & 97 & 44 & 9 & 4 & 6 & 3 \\
\hline 12. & Edit for content and organization & 47 & 22 & 23 & 11 & 60 & 28 & 70 & 33 & 12 & 6 \\
\hline 13. & $\begin{array}{l}\text { Like to change or make your ideas clearer } \\
\text { while in the process of writing }\end{array}$ & & & 15 & 7 & 46 & 21 & 80 & 37 & 75 & 34 \\
\hline \multicolumn{12}{|c|}{ After Writing } \\
\hline 14. & $\begin{array}{l}\text { Revise your content and make your ideas } \\
\text { clearer. }\end{array}$ & 4 & 2 & 68 & 31 & 25 & 11 & 10 & 5 & 144 & 52 \\
\hline 15. & Revise and improve your organization & 11 & 5 & 91 & 43 & 45 & 21 & 62 & 29 & 4 & 2 \\
\hline 16. & $\begin{array}{l}\text { Edit format, vocabulary, grammar, spelling and } \\
\text { punctuation. }\end{array}$ & 11 & 5 & 69 & 32 & 83 & 39 & 48 & 22 & 4 & 2 \\
\hline 17. & $\begin{array}{l}\text { Discuss with fellow students to get feedback on } \\
\text { how you can improve it. }\end{array}$ & 21 & 9 & 73 & 33 & 53 & 24 & 66 & 30 & 10 & 5 \\
\hline 18. & $\begin{array}{l}\text { Show it to the teacher to get feedback about } \\
\text { your writing. }\end{array}$ & 86 & 39 & 61 & 28 & 46 & 21 & 15 & 7 & 11 & 5 \\
\hline 19. & $\begin{array}{l}\text { Evaluate other students' writing and give them } \\
\text { your feedback on how they can improve. }\end{array}$ & 57 & 29 & 24 & 12 & 44 & 23 & 59 & 30 & 11 & 6 \\
\hline
\end{tabular}

On the basis of the entire analysis of student questionnaires, it was found that most of the students were quite aware of the importance of writing skills for business management students, the importance of good business writing skills and the ability to write good reports and proposals. Similarly, they were aware of their own proficiency in business writing and wished to improve it

Many of the students also knew that teaching of writing in their classrooms lacked a lot. Teachers attempted to improve students' writing but their teaching was more theoretical than practical. Pedagogical practices for teaching writing was not process oriented, rather more product oriented.

Table 2. Important Aspects Of Teaching Writing

\begin{tabular}{|c|c|c|c|c|c|c|c|c|c|c|}
\hline \multirow{3}{*}{ Item } & \multirow{3}{*}{$\begin{array}{l}\text { Degree of } \\
\text { Significance }\end{array}$} & \multicolumn{2}{|c|}{5} & \multicolumn{2}{|c|}{4} & \multicolumn{2}{|l|}{3} & \multicolumn{2}{|l|}{2} & 1 \\
\hline & & \multirow{2}{*}{$\begin{array}{l}\text { Res } \\
\text { pon } \\
\text { den } \\
\text { ts }\end{array}$} & \multirow[t]{2}{*}{$\%$} & \multirow[t]{2}{*}{$\begin{array}{l}\text { Respo } \\
\text { ndents }\end{array}$} & \multirow[t]{2}{*}{$\%$} & \multirow[t]{2}{*}{$\begin{array}{l}\text { Respon } \\
\text { dents }\end{array}$} & \multirow[t]{2}{*}{$\%$} & \multirow[t]{2}{*}{$\begin{array}{l}\text { Respo } \\
\text { ndents }\end{array}$} & \multirow[t]{2}{*}{$\%$} & \multirow{2}{*}{$\begin{array}{l}\text { Resp } \\
\text { onde } \\
\text { nts }\end{array}$} \\
\hline & & & & & & & & & & \\
\hline 1. & Format & 19 & 59 & 9 & 28 & 2 & 6 & 2 & 6 & - \\
\hline 2. & Language accuracy & 16 & 50 & 9 & 28 & 5 & 16 & 2 & 6 & - \\
\hline 3. & Sentence structures & 17 & 53 & 11 & 34 & 2 & 6 & 2 & 6 & - \\
\hline 4. & Content & 23 & 72 & 6 & 19 & 2 & 6 & 1 & 3 & - \\
\hline 5. & Vocabulary & 16 & 50 & 9 & 28 & 4 & 13 & 3 & 9 & - \\
\hline 6. & Spelling & 21 & 66 & 7 & 22 & 2 & 6 & 1 & 3 & 3 \\
\hline 7. & Punctuation & 19 & 59 & 6 & 19 & 5 & 16 & 2 & 6 & - \\
\hline 8. & Organization of ideas & 21 & 66 & 9 & 28 & 1 & 3 & 1 & 3 & - \\
\hline 9. & Cohesiveness & 22 & 69 & 9 & 28 & - & & 1 & 3 & \\
\hline 10. & Paragraph & 13 & 41 & 11 & 34 & 6 & 19 & 2 & 6 & - \\
\hline
\end{tabular}


On the basis of the above analysis, it is understood that most of the teachers stated that organization of ideas was an important element in teaching writing. It is also understood that majority of the teachers stated that cohesiveness was very important aspect of teaching writing. It can be inferred that most of the teachers treated that paragraph writing is an important aspect in teaching writing.

\section{Discussion}

The two research questions focused on three broad areas: i) the impact of the process genre approach on students' writing of business reports and proposals, ii) the effectiveness of the use of process genre approach in developing business writing skill of management students, and iii) the effectiveness of the process genre approach in improving the overall writing skill of management students.

The key findings of the present study with regard to the two research questions are presented. At the pre-intervention stage, the findings based on the pre-test result of the students proved that the students' performance in business writing, particularly in the area of writing business reports and proposals was quite poor. The pre-test results revealed that the students were unable to write linguistically correct and structurally appropriate business reports and proposals.

The major findings of the present study are summed up as follow:

- The students failed to write their ideas and arguments in an organized manner and their writing lacked contextual ideas, logical sequence and basic structure such as introduction, body and conclusion. There were linguistic errors in terms of syntactical structures, lexical errors, inappropriate use of linkers, verb patterns and so on in their write-ups.

- The performance of majority of the students (82\%) disclosed that they were poor in constructing grammatically correct sentences, even simple sentences sometimes..

- Majority (85\%) of the students failed in using appropriate mechanics of writing. The columns of some of the students had numerous spelling errors in their writing. This was due to the fact that these students had completed their graduation in regional language medium and studied English only as a compulsory subject.

- In most of the cases, the learners' choice of vocabulary was inappropriate in their writing.

- Students did not have enough knowledge about different forms of business letters and also how to write those letters using proper format, structure, and vocabulary. They did not have enough idea about the steps involved in writing business reports and proposals.

- After the intervention, the post-test was conducted among the sample of students. The comparison between the students' pre-test performance with their post-test performance showed that there was significant improvement in their business writing after the instructional intervention. 
- During the post-intervention questionnaires with the students, $77 \%$ of the students stated that they had gained a lot from the intervention. They had learnt many things regarding writing in general and business writing in particular after attending the intervention and it had improved their writing skills as a whole. They also shared that the intervention had boosted their confidence in writing.

\section{Conclusion}

It can be concluded that the use of the process genre approach for teaching business writing to management students during the intervention had become successful in achieving the desired goal. It helped students in developing better writing proficiency and enhancing their business writing skill.

It is evident that the process genre approach enabled the students to write business reports and proposals effectively and appropriately. It is indicated that the students were able to write the contents in their respective composition in an organized manner and also at the paragraph level, i.e. using the topic sentence and supporting sentences.

- The present approach assisted the learners in identifying the purpose, context, situation and style of writing a business report or proposal with adequate support and motivation.

- $70 \%$ of the students avoided using colloquial language and contractions while writing business reports and proposals in the post-intervention test. They were able to write cohesive texts using appropriate vocabulary, verb forms and linkers with less number of errors. It was also found that their writing was better organized in terms of arranging ideas coherently and in proper sequence.

- The learners used appropriate business vocabulary in their business report and proposal writing.

Based on the above analysis, the study provided the answer to the research questions and proved that the process genre approach impacted positively on the students' writing performance.

\section{References}

Azhar, M.A., Kiran, S. \& Khan, T. (2016). Teaching writing skill based on process genre approach in community learning context. From proceedings of SOCIOINT $20163^{\text {rd }}$ International Conference of Education, Social Sciences and Humanities. Downloaded from http://www.ocerint.org/socioint16 e-proceedings/abstracts/papers/336.pdf

Badger, R., \& White, G. (2000). Product, process and genre: Approaches to writing in EAP. ELT Journal, 54(2), 153-160.

Bandura, A. (1982). Self-efficacy mechanism in human agency. American Psychologist, 37(2), 122-147. $\quad$ http://dx.doi.org/10.1037/0003066X.37.2.122 
Bandura, A., \& National Inst of Mental Health. (1986). Prentice-Hall series in social learning theory. Social foundations of thought and action: A social cognitive theory. Englewood Cliffs, NJ, US: Prentice-Hall, Inc.

Bhatia, V. (1993). Analyzing Genre: language use in professional settings. London: Longman.

Brown, H. D. (1994). Teaching by principles: An interactive approach to language pedagogy. Englewood Cliffs, NJ: Prentice Hall Regents.

Feez, S. \& Joyce, H. (1998). Text-based syllabus design. Sydney: National Centre for English Language Teaching and Research, Macquarie University.

Flower, L. \& Hayes, J. (1981). A cognitive process theory of writing. College Composition and Communication, 32,365-387.

Hyland, K. (2003). Second language writing. New York: Cambridge University Press.

Hyland, K. (2003). Genre-based pedagogies: A social response to process. Journal of Second Language Writing, 12, 17-29.

Kroll, B. (1990). What does time buy? ESL students' performance on home versus class compositions. In B. Kroll (Ed.), Second language writing: Research insights for the classroom. Cambridge: Cambridge University Press.

Mohamed Kassem, M. A. (2017). Developing business writing skills and reducing writing anxiety of EFL learners through Wikis. English Language Teaching, 10(3), 151-164.

Nordquist, R. (2018, June 17). What is business writing? Definition, tips and examples. Retrieved from https://www.thoughtco.com/what-is-businesswriting-1689188

Nunan, D. (1999). Second language teaching and learning. Boston: Heinle \& Heinle Publisher.

Pujianto, D., Emilia, E. \& Sudarsono, M.I. (2014). A process-genre approach to teaching writing report text to senior high school students. Indonesian Journal of Applied Linguistics, 4(1), 99-110.

Reonal, A.M. (2015). Process-genre approach in teaching expository writing in secondary ESL classes. International Journal of Social Science and Humanities Research. 3(3), 187-191.

Richards, J. \& Renandya, W. (2002). Methodology in language teaching: an anthology of current practice. Cambridge: Cambridge University Press.

Swales, J. M. (1990). Genre analysis: English in academic and research settings. Cambridge: Cambridge University Press.

Swain, M. (1997) Collaborative dialogue: Its contribution to second language learning. Revista Canaria de Estudios Ingleses, 34,115-32. 
Swain, M. (2000) The output hypothesis and beyond: Mediating acquisition through collaborative dialogue. In J.P. Lantolf (ed.) Sociocultural Theory and Second Language Learning (pp. 97-114). Oxford: Oxford University Press.

Tangekiengsirisin, S. (2006). Approaches to teaching second language writing. Language institute journal, 3, 1-26.

Tribble, C. 1996. Writing. Oxford: Oxford University Press.

Vygotsky, L. S. (1978). Mind in society: The development of higher psychological processes. Cambridge, MA: Harvard University Press. 